\begin{tabular}{lll}
\hline Bentham open & The Open Sports Sciences Journal \\
CrossMark & Content list available at: www.benthamopen.com/TOSSJ/ & DOI: $10.2174 / 1875399 X 01609010003$ \\
\hline
\end{tabular}

\title{
Revisiting the Role of Football Spectators' Behavioral Intentions and its Antecedents
}

\author{
Rui Biscaia ${ }^{1,2, *}$ \\ ${ }^{I}$ Escola de Turismo, Desporto \& Hospitalidade, Universidade Europeia, Lisboa, Estrada da Correia, no. 53, 1500-210 \\ Lisboa, Portugal \\ ${ }^{2}$ CIPER, Faculdade de Motricidade Humana, Universidade de Lisboa, Estrada da Costa, 1495-688 Cruz Quebrada, \\ Portugal
}

Received: July 16, 2015

Revised: August 18, 2015

Accepted: September 07, 2015

\begin{abstract}
Football is one of the most rooted sports worldwide attracting millions of spectators, but clubs face an increasing competition of other leisure activities. Understanding how to increase spectators' behavioral intentions towards their favorite football teams is paramount for sport managers, given that a behavioral intention represents a measure of how much a person is willing to engage in a specific behavior. Thus, the purposes of this study were (1) to explain the role of spectators' behavioral intentions, and (2) to highlight its antecedents within the football context. In doing so, this study starts by providing a review of consumption-related aspects that have been associated with football spectators' behavioral intentions, such as emotions experienced during the games, service quality, team brand associations and satisfaction. Subsequently, the main findings from previous studies conducted with football spectators are highlighted and managerial implications are suggested in order to aid football clubs at providing good overall consumption experiences to their spectators, and thus contributing to increase attendance levels. Finally, future research avenues are suggested in order to expand our understanding on how to strengthen the link between football spectators and their teams, with subsequent associated benefits.
\end{abstract}

Keywords: Behavioral Intentions, Emotions, Football, Service Quality, Spectators, Team Brand Associations.

\section{INTRODUCTION}

Football is one of the most rooted sports worldwide, and attending football games is a popular leisure activity in contemporary societies. This is particularly evident in Europe where every year millions of passionate fans invest time, energy, and money in supporting their favorite teams [1]. The top 20 European clubs generated combined revenues of over $€ 6.2$ billion in $2013 / 14$ including about $20 \%$ in gate receipts [2]. However, due to the unstable economic environment in many countries, the emergence of new technologies, and the increased importance of selling broadcasting rights, the challenge for clubs is to retain this high demand [3]. Also, the increasing competition from other leisure activities leads professional teams to compete with other organizations for the time and disposable money of potential consumers [4]. Thus, clubs need to provide memorable experiences at the stadium in order to strengthen the link with spectators and increase their intentions to attend more games over time [5].

Achieving high attendance levels in a regular basis is vital for sport clubs due to the impact on ticket sales and other match day revenues, while also contributing to make the games more attractive to others. In this sense, recent studies have focused on fans' experiences at the stadium to understand how to strengthen their positive behavioral intentions towards the team [3,5]. Satisfaction with team games has been referred as an antecedent of behavioral intentions [4]. Also, emotions experienced during the matches [6], service quality [7], and team brand associations [8] are other consumption-related factors often mentioned as having a direct or indirect role (i.e., via satisfaction) at increasing

* Address correspondence to this author at the Escola de Turismo, Desporto \& Hospitalidade, Universidade Europeia, Lisboa, Estrada da Correia, no. 53, 1500-210 Lisboa, Portugal; Tel: +351 210309 900; E-mail: rui.biscaia@universidadeeuropeia.pt 
spectators' behavioral intentions. Based on the sport management and marketing literature, understanding how to increase spectators' behavioral intentions should be a strategic goal for sport clubs in order to strengthen financial sustainability $[3,4,6]$. This assumes particular relevance in the European football context due to the global popularity of this sport and recent evidences of indebtedness in several European leagues and clubs [9, 10]. Thus, through a comprehensive review of studies published in sport management and marketing journals about football, the purposes of this study were to explain the importance of spectators' behavioral intentions towards the teams, and to highlight consumption-related factors that contribute to understand how to increase spectators' behavioral intentions within the football context. While this study is mainly directed towards managers working in football clubs, it may also provide guidance to managers working in other sport contexts, and other entertainment industries.

\section{METHOD}

\section{Eligibility Criteria}

The current review of the literature is based on articles published in the Journal of Sport Management (JSM), European Sport Marketing Quarterly (ESMQ), International Journal of Sports Marketing \& Sponsorship (IJSMS), Sport Management Review (SMR) and Sport Marketing Quarterly (SMQ). The decision to focus on these journals was based on the international ranking of sport management journals conducted by Woratschek and colleagues [11], and the bibliometric studies of citations to sport management and marketing journals indicating these journals as the ones with most quality, prestige and impact in this field of study $[12,13]$. In addition, only empirical studies conducted within the football context and testing the psychometric properties of the proposed constructs were considered to be eligible in order to allow the identification of valid measures to be potentially used in subsequent studies.

\section{Search Strategy and Study Selection}

A search of peer-reviewed articles published between January 2000 and March 2015 (including online ahead of print publication) was conducted in the databases of JSM, SMR and SMQ. As for the ESMQ and IJSMS, the search commenced in 2001 and 2002, respectively, given that these journals only became available online after these dates. The decision to restrict the selection to studies published since these dates is also based on the fact that recent studies testing construct validity have highlighted some weaknesses in the external validity of older studies. For instance, in 1995, McDonald and colleagues proposed the TEAMQUAL scale to assess service quality in professional sports [14]; yet, the psychometric properties of the scale were not examined [4, 7]. The searches were conducted in the journals' webpages and included the analysis of article titles by considering terms related with the sport and the events (football or soccer, professional team sports, sporting events), the actual consumers of the event (spectators, attendees, fans), the consumption-related experiences (sporting event experience, emotions, service quality, team brand associations or image, satisfaction), and the future behaviors (behavioral intentions, revisit intentions, word-of-mouth, recommendations, purchase intentions). Other sources for identifying studies included manual cross-referencing of bibliographies cited in these journals [15] leading to the identification of studies in other scientific journals focusing on sport and leisure management (European Journal of Marketing, Managing Leisure and Revista Intercontinental de Gestão Desportiva). At this stage, all relevant articles were retrieved and read in order to identify the studies that met the eligibility criteria.

\section{RESULTS AND DISCUSSION}

This review of the literature is focused on studies about actual experiences at the stadium in order to analyze football spectators' behavioral intentions and their antecedents. It is important to note that due to the focus on football (referred to as soccer in the United States), the studies conducted in different sport settings including, for example 'American football' (referred to as football in the United States) were not considered. The literature search yielded 30 relevant empirical studies with measures to assess football spectators' behavioral intentions, service quality perceptions, emotions experienced during the matches, team brand associations and satisfaction. Three additional empirical studies that were identified through manual searches and cross-referencing were added, leading to a total of 33 studies that are presented in the sections below with measures to assess football spectators' behavioral intentions (Table 1) and their antecedents (Tables 2-5).

\section{The Importance of Spectators' Behavioral Intentions}

The analysis of behavioral intentions is important for understanding if a relationship between a spectator and a club 
will continue in the future and generate more revenues. The theoretical rationale for this assumption is that a behavioral intention represents a measure on how much a person is willing to engage in a particular behavior [16]. Consistently, a behavioral intention serves as context-specific representation of a goal-oriented behavior [17], and can represent either favorable or unfavorable outcomes to a club. As noted by Zeithaml and colleagues [18], unfavorable behavioral intentions include aspects such as saying negative things about the organization, switching to competitors, complaining to external agencies and/or decreasing the amount of business with the organization. In turn, favorable behavioral intentions are related with saying positive things about the organization, recommending its services to others, remaining loyal, spending more money in products and services and/or paying a price premium [18].

Table 1. Measures used in prior studies to assess football spectators' behavioral intentions.

\begin{tabular}{|c|c|}
\hline Measures of Behavioral Intentions & Year and Sources \\
\hline $\begin{array}{l}\text { Game attendance } \\
\text { Probability to attend more team games in the future. } \\
\text { Probability to make the same choice if having to attend a team game again. }\end{array}$ & $\begin{array}{l}2005[21] \\
2008[22] \\
2008[23]\end{array}$ \\
\hline $\begin{array}{l}\text { Game recommendation } \\
\text { Likelihood to recommend team games to friends and family (or to others, in general). }\end{array}$ & $2012[25]$ \\
\hline $\begin{array}{l}\text { Other forms of team support } \\
\text { Likelihood to purchase other products and services of the team (e.g. team-related merchandise). } \\
\text { Likelihood to watch team games on TV. } \\
\text { Likelihood to participate in discussions about the team. } \\
\text { Likelihood to wear the team colors and logo. }\end{array}$ & $\begin{array}{l}2013[4] \\
2013[8] \\
2013[20] \\
2013[3] \\
2014[27] \\
2014[28]\end{array}$ \\
\hline
\end{tabular}

In spectator sport research, the concept of behavioral intentions has been referred as a favorable intention to attend future games, recommend them to others and remain supporting the team through different forms [7]. This measure has been successfully used in previous studies concerning the antecedents of spectators' behavioral intentions [8, 19]. In addition, previous studies have noted that spectators' behavioral intentions are associated with their actual behaviors [20]. Although a behavioral intention is not the same as an actual behavior, a consumer's intention is vital in guiding his/her behavior [16]. Thus, drawing on previous research, one can say that a behavioral intention is a paramount measure to understand future actions of football spectators towards their teams. Table 1 summarizes the measures used in prior studies to assess football spectators' behavioral intentions.

\section{Antecedents of Behavioral Intentions}

Understanding the antecedents of spectators' behavioral intentions should be a priority for football clubs as a way to increase team support and to potentiate revenues over the season. Also, through an increase in spectators' attendance levels, clubs tend to become more attractive to the sponsoring brands, given that sponsors want to expose their products to a great amount of potential consumers, and sport teams with more regular supporters at the stadium constitute more attractive targets [20].

Prior studies suggest that a good impression caused by a sporting event can determine a spectator's intention to continue supporting the team in the future [5]. To this extent, spectators' experiences at the stadium are paramount to understand their behavioral intentions. Edvardsson [29] mentions that cognitive and emotional reactions co-exist during consumption episodes. In this sense, service quality perceptions and emotions experienced at the stadium constitute important aspects of the consumption experience. Also, the interactions spectator-team during sporting events are vital to enhance sport brand perceptions [30]. Furthermore, satisfaction has been suggested as a key indicator of spectators' consumption experiences [4]. On the basis of previous literature, the constructs of service quality, emotions, team brand associations and satisfaction constitute the basis of the current review to understand how to increase football spectators' behavioral intentions.

\section{Service Quality}

Service quality has been referred as an attitude or global judgment about the superiority of a given service [31]. That is, quality is seen as the consumer's impression regarding the excellence of the service provided by an organization. Numerous scholars have examined service quality in spectator sport settings [4, 7, 32]; yet, it is important to consider the specific features of each sport when assessing service quality. For example, the five-dimension SPORTSERV scale [33] and the eleven-dimension model presented by Biscaia and colleagues [4] are examples of scales used in the football context. However, despite the lack of consensus on the appropriate dimensions of the existing scales, it is 
widely accepted that good perceptions of service quality lead to competitive advantages $[4,19,32]$.

Providing high-quality services is paramount for football clubs, given that service quality represents a proxy measure of managers' performance, while also contributing to the organization's positioning, and to enhancing satisfaction and behavioral intentions [23,32]. Theodorakis and colleagues [3] found that good perceptions of service quality lead to increased satisfaction, which in turn leads to positive behavioral intentions. Also, Biscaia and colleagues [4] noted that service quality dimensions favor both overall satisfaction and behavioral intentions. Drawing on previous literature, service quality represents an antecedent of football spectators' behavioral intentions, both in a direct way as well as via satisfaction. Table $\mathbf{2}$ summarizes the measures used in prior studies for assessing service quality in the football context and its relationship with behavioral intentions.

Table 2. Measures of service quality in football context and its relationship with behavioral intentions.

\begin{tabular}{|c|c|c|}
\hline $\begin{array}{l}\text { Year and } \\
\text { Source }\end{array}$ & Measures of Service Quality & Predictors of Behavioral Intentions \\
\hline $2008[23]$ & Tangibles, Responsiveness, Access, Security and Reliability. & Tangibles, Responsiveness, Access, Reliability. \\
\hline $2011[33]$ & Tangibles, Responsiveness, Access, Security and Reliability. & Not tested. \\
\hline $2012[34]$ & $\begin{array}{c}\text { Tangibles, Responsiveness, Access, Security, Reliability, Auditory and Game } \\
\text { quality. }\end{array}$ & Not tested. \\
\hline $2013[3]$ & $\begin{array}{l}\text { Functional quality (Tangibles, Responsiveness, Access, Security and } \\
\text { Reliability) and Outcome quality (Team performance and Game quality). }\end{array}$ & $\begin{array}{l}\text { Outcome quality (direct effect). Functional quality } \\
\text { (via Satisfaction). }\end{array}$ \\
\hline $2013[4]$ & $\begin{array}{c}\text { Player performance, Opponent characteristics, Referees, Frontline employees, } \\
\text { Facility assess, Seat space, Facility design, Game atmosphere and Crowd } \\
\text { experience. }\end{array}$ & $\begin{array}{c}\text { Referees, Security and Crowd experience (direct } \\
\text { effect). } \\
\text { Player performance, Opponent characteristics, Crowd } \\
\text { experience, Game atmosphere and Referees (via } \\
\text { Satisfaction). }\end{array}$ \\
\hline $2014[28]$ & Game quality, Augment service, Interaction, Outcome and Environment. & $\begin{array}{l}\text { Game quality, Augment service, outcome and } \\
\text { Environment (via Satisfaction). }\end{array}$ \\
\hline
\end{tabular}

\section{Emotions}

It is commonly accepted that an emotion is a reaction to actual or imagined stimulus events involving subjective experiences (cognitive component), physiological processes (arousal component), and action tendencies [35]. Consistently, Bagozzi and colleagues [36] define an emotion as a "state of readiness that arises from cognitive appraisals of events or thoughts; has a phenomenological tone; is accompanied by physiological processes; is often expressed physically (e.g., gestures, posture, facial features); and may result in specific actions to affirm or cope with the emotion, depending on its nature and meaning for the person having it." (p. 184)

There is a growing interest in spectators' emotions due to the unique form of experiential consumption in sports [6, 24, 37]. Sporting events can evoke a wide range of pleasant (e.g., joy and excitement) and unpleasant emotions (e.g., anger and dejection), which suggest that sport teams have the potential to capitalize the emotional relationship shared with fans [38, 39]. Complementarily, it is important to note that context analysis is essential for studying emotions [40], and prior studies have reported that unpleasant emotions can negatively influence spectators' satisfaction [41] and behavioral intentions [42], while pleasant emotions contribute in a positive way to increase these outcomes [24]. Thus, emotions experienced during team matches seem to have a direct impact on spectators' behavioral intentions, as well as an indirect impact that is mediated by satisfaction. With this in mind, understanding the different stimuli causing emotional reactions should be a focal point for sport managers working in the football context. Table $\mathbf{3}$ summarizes the emotions examined in prior studies conducted with football spectators and its relationship with behavioral intentions.

Table 3. Emotional measures used in football context and its relationship with behavioral intentions.

\begin{tabular}{|c|c|c|}
\hline Year and Source & Measures of Emotions & Predictors of Behavioral Intentions \\
\hline $2004[42]$ & Joy, Anger, Sadness, Excitement, Worry and Love. & Excitement. \\
\hline $2012[24]$ & Anxiety, Dejection, Anger and Joy. & Joy (via satisfaction). \\
\hline
\end{tabular}

\section{Team Brand Associations}

According to Aaker [43], brand associations are the thoughts that an individual holds in memory linked to a brand, and these thoughts are suggested to be vital when making consumption decisions [44]. Conceptually, Keller [45] 
distinguishes brand associations into attributes, benefits and attitudes. Attributes are the features of each brand including product-related (physical composition of the product, or service requirements) and non-product-related (external aspects of the product or service linked to the purchase or consumption). Benefits are related to the meaning consumers attach to the product/service, and can be functional, symbolic or experiential [46]. In turn, attitudes represent the overall evaluation of the brand depending on the attributes and benefits of the brand. These brand associations may vary according to their favorability, strength and uniqueness, and the set of mental associations held by consumers allows the creation of a brand image [47].

In the sports marketplace, the analysis of team brand associations represents an important stream of research. The interest in this topic is due to the unique consumer setting in sport where fans often develop highly emotional bonds with their favorite teams [24, 38]. Previous studies suggest that managing a team as a brand aids to dilute the effect of team performance during the season, contributing to provide superior service experiences and to increase long-term profitability [47]. Recent studies conducted with football fans have highlighted that brand associations are important to enhance spectators' satisfaction [48] and behavioral intentions [8]. Based on previous literature, one can argue that team brand associations represent an antecedent of both satisfaction and behavioral intentions. Table 4 summarizes the studies on team brand associations within the football context.

Table 4. Measures of team brand associations in football context and its relationship with behavioral intentions.

\begin{tabular}{|c|c|c|}
\hline $\begin{array}{l}\text { Year and } \\
\text { Source }\end{array}$ & Measures of Team Brand Associations & $\begin{array}{l}\text { Predictors of Behavioral } \\
\text { Intentions }\end{array}$ \\
\hline $2005[23]$ & $\begin{array}{l}\text { Product-related attributes (Athletic success, Star players, Coach and Management), Non-product- } \\
\text { related attributes (Logo, Stadium, Stadium atmosphere and Regional importance) and Benefits } \\
\text { (Fan identification, Interest of family and friends, Nostalgia and Escape). }\end{array}$ & $\begin{array}{l}\text { Product-related attributes, Non- } \\
\text { product-related attributes and } \\
\text { Benefits. }\end{array}$ \\
\hline $2005[47]$ & $\begin{array}{l}\text { Product-related attributes (Success, general team performance and Head coach), Non-product- } \\
\text { related attributes (Logo and club colors, Club history and tradition, management, stadium, Club } \\
\text { culture and values, Fans, Sponsor or owner, and Regional provenance) and Benefits (Fan } \\
\text { identification, Pride in place, Peer group acceptance, Escape, Socialization, Emotions, Nostalgia } \\
\text { and Escape). }\end{array}$ & $\begin{array}{l}\text { Benefits (via psychological } \\
\text { commitment with the team). }\end{array}$ \\
\hline $2006[48]$ & Club status, Efficient management and Club sporting results. & Not tested. \\
\hline 2008 [22] & $\begin{array}{c}\text { Product-related attributes (Team, Head coach, Success, Star players and Team Performance), Non- } \\
\text { product-related attributes (Logo and club colors, Club history and tradition, Stadium, and Fans), } \\
\text { Benefits (Identification, Peer-group acceptance, Escape, Socializing, Emotions, Nostalgia and } \\
\text { Entertainment) and Attitudes (affect). }\end{array}$ & Attitudes. \\
\hline $2013[8]$ & $\begin{array}{l}\text { Brand mark, Concessions, Social interaction, Commitment, Team history, Organizational } \\
\text { Attributes, Team success, Head coach, Management and Stadium. }\end{array}$ & $\begin{array}{l}\text { Brand associations (overall } \\
\text { measure). }\end{array}$ \\
\hline 2015 [49] & $\begin{array}{l}\text { Brand mark, Concessions, Social interaction, Commitment, Team history, Organizational } \\
\text { Attributes, Team success, Head coach, Management and Stadium. }\end{array}$ & $\begin{array}{l}\text { Social interaction, Team History } \\
\text { and Team success. }\end{array}$ \\
\hline
\end{tabular}

\section{Satisfaction}

Cronin and Taylor [50] refer to satisfaction as the consumer experience emerging as a reaction of the service encounters. In line with this view, consumer satisfaction has been described as a summary of cognitive and affective reactions regarding service encounters $[6,24]$. The analysis of consumer satisfaction is paramount for sport clubs due to two important reasons. First, consumer satisfaction depends on consumer's subjective perceptions of service performance rather than the organization's standards of quality [51], and second, it has been pointed out as an antecedent of behavioral intentions [6,7]. As such, one can argue that satisfaction is simultaneously a criterion to evaluate the service provided by an organization and a measure to understand consumers' behavioral intentions. Conceptually, consumer satisfaction can be measured either as transaction-specific or an overall level. Transactionspecific satisfaction refers to the evaluation of a specific service encounter, and is deemed appropriate when the idea is to understand variability associated with service delivery over a period of time [19]. In turn, overall satisfaction represents the cumulative evaluation of all service encounters over the time, and has been identified as a more relevant measure for understanding consumer future responses [52].

In the context of spectator sports, overall satisfaction refers to the spectators' experience resulting from attending team matches during the season [24]. Due to the experiential nature of satisfaction, the analysis of consumption experiences is a cornerstone to understand its antecedents. In this sense, service quality, game-related emotions, and team brand associations represent important antecedents of spectators' satisfaction. Also, numerous studies suggest that satisfied spectators are more likely to continue supporting the team in the future. For example, Biscaia and colleagues 
[4] and Theodorakis and colleagues [3] provide empirical evidence of the positive link between football spectators' satisfaction and behavioral intentions. Thus, on the basis of previous literature, satisfaction seems to be an important indicator to properly understand football spectators' behavioral intentions. Table $\mathbf{5}$ summarizes recent studies on football spectators' satisfaction.

Table 5. Prior studies examining satisfaction and its link with behavioral intentions in the football context.

\begin{tabular}{|c|c|c|}
\hline Source & Positive contributors of Satisfaction & Impact on Behavioral Intentions \\
\hline $2003[53]$ & Team identification. & Yes. \\
\hline $2006[48]$ & Motives and Brand Associations. & Not tested. \\
\hline $2011[33]$ & Overall quality. & Not tested. \\
\hline $2012[24]$ & Joy. & Yes. \\
\hline $2013[4]$ & Player performance, Referees and Game atmosphere. & Yes. \\
\hline $2013[3]$ & Functional quality. & Yes. \\
\hline $2014[28]$ & Game quality, Augment service, Outcome and Environment. & Yes. \\
\hline
\end{tabular}

\section{CONCLUSION AND IMPLICATIONS}

By focusing on the concept of behavioral intentions and its antecedents, the current study reviews the importance of spectators' behavioral intentions within the football context. The antecedents of behavioral intentions described in this study are focused on spectators' experiences at the stadium, highlighting that clubs should put particular attention on service quality, consumption-related emotions and team brand associations in order to generate satisfactory experiences over the season and to increase behavioral intentions. An important aspect is that, rather than suggesting service quality as a specific type of brand association [30], the current study considers service quality (consumer's judgment of the overall excellence with respect to its intended purposes) and brand associations (anything linked in memory to the brand) as two separate factors [44].

A spectator's favorable behavioral intention towards the team is paramount to generate more income, given that the number of spectators and associated spending, directly or indirectly impacts the sales and the interest of the media and sponsors $[54,55]$. Thus, clubs should create dynamic relationships with their supporters in order to increase attendance levels and increase their value for potential sponsors. Biscaia and colleagues [24] found that spectators' joy during the games is vital to increase satisfaction, which in turn leads to positive behavioral intentions. The authors also noted that dejection negatively impacts behavioral intentions. Thus, conducting periodical interviews with spectators to gather their opinion about the club's overall performance at match-day may prove to be a pivotal step to understand the stimuli that cause those emotions, and thus, contributing to potentiate pleasant environments. On the basis of previous literature with football spectators, the on-field performance seems to be a vital predictor of spectators' satisfaction and behavioral intentions [3, 49]. Although the outcome of the games is unpredictable, clubs should use players in their marketing communications because they are part of the core product. In addition, a good stadium atmosphere is important to increase spectators' satisfaction [4]. Thus, by organizing ancillary events before the games and at half-time, promoting spectators' rituals, offering memorabilia or creating an interactive relationship with spectators through the megascreens $[4,24]$, clubs could strengthen the link with spectators and potentiate their future positive behaviors.

Complementarily, football clubs need to go beyond their status as mere sport teams and establish themselves as brands in their own right [38]. Real Madrid (Spain) and Manchester United (England) are good examples of football clubs who became strong brands worldwide [2]. Thus, clubs should use the knowledge regarding consumers' experiences in order to build a brand that instills trust. This will aid to generate additional revenues through the sale of a variety of goods and services, reduce the effect of team performance, and protect against the competition of other leisure activities. Based on prior literature, developing the brand foundations around aspects such as team logo and colors, socialization, fans' commitment, team history and tradition, and the stadium called as the team's home may prove to be of paramount importance to create a link with spectators and trigger positive behavioral intentions [8, 56].

Nevertheless, it is important to note that while the current study is focused on the aspects that positively influence spectators' behavioral intentions, there are constraints that may negatively impact future behaviors towards the team. In spectator sports, a constraint refers to an aspect that inhibits a person from attending a sporting event [57], and can be further divided into internal constraints and external constraints. As noted by Kim and Trail [57], internal constraints are concerned with internal psychological cognitions that deter behavior (e.g., lack of knowledge, lack of success, or no 
interest from others), while external constraints are related with social or environmental aspects that decrease the likelihood of the individual performing the behavior (e.g., financial cost, leisure alternatives, parking or location). Cardoso and colleagues [58] conducted a study in conjunction with the sport managers of a Portuguese professional football team, and found that leisure alternatives, participation sport alternatives and stadium location were the strongest constraints for spectators. Therefore, clubs should also invest at identifying the constraints of potential spectators and developing strategies to reduce those constraints [57, 59].

\section{RESEARCH DIRECTIONS}

A suggested focus for future research would be to propose and empirically examine a conceptual framework for understanding the antecedents of football spectators' behavioral intentions. While the current study highlights constructs that have been linked to behavioral intentions such as service quality, emotions, team brand associations and satisfaction, all these constructs have been examined separately in previous studies. This aspect may raise some questions related to conceptual distinctions and construct validity. Thus, the inclusion of these constructs in a single model may represent an important step to better clarify the factors contributing to increase spectators' attendance over the season. In addition, previous studies highlight that sponsoring brands are more willing to invest in teams with a strong bond with their supporters [20]. It means that understanding how to strengthen the spectators' bond with the team is paramount not just due to the direct role on sales, but also because of the increased ability to negotiate with sponsors.

The development of longitudinal studies to examine the antecedents of spectators' behavioral intentions would also be an interesting research line, given that spectators' perceptions of service delivery can vary over the season based on a variety of aspects such as managerial decisions or the team's performance during the competitions [32]. Also, collecting data at different points of the season with the same participants would increase the accuracy of the causal relationships between the proposed constructs.

Another suggestion for future research is related to the moderating role of membership status for understanding spectators' experiences and their future intentions towards the team. Membership programs are a common strategy used by European football teams to generate a stable source of revenue [34, 49, 60]. Club members pay a monthly or annual fee in order to have discounts when buying season ticket, other team-related products, and in some clubs even voting rights for board elections [25]. Prior research suggests that club members and/or season ticket holders are often more identified with the team [61]. Also, it has been suggested that members and non-members often have different opinions about the sport organization [62]. Thus, examining whether the evaluation of the proposed antecedents (i.e., emotions, service quality, team brand associations and satisfaction) and its structural relationships with behavioral intentions vary across club members and non-members would aid sport managers at designing strategies for different types of customers.

Additionally, while this study reviews the importance of spectators' behavioral intentions within the football context, future studies could conduct a systematic review of the literature $[15,63]$ concerning behavioral intentions for spectator sports in general in order to strengthen our understanding of how to enhance sport spectators' behavioral intentions and its link with actual behaviors in different sport scenarios.

In summary, the current study focuses on football spectators' experiences at the stadium and its role on behavioral intentions. In doing so, this study reviews aspects such as service quality, consumption-related emotions, team brand associations and satisfaction, and provides cues for future research aiming to understand how to strengthen the link between spectators and sport clubs. Although this study is oriented to managers working in the football context, it provides information that may be useful for managing other spectator and/or participatory activities.

\section{CONFLICT OF INTEREST}

The author confirms that this article content has no conflict of interest.

\section{ACKNOWLEDGEMENTS}

Declared none

\section{REFERENCES}

[1] Vallerand RJ, Ntoumanis N, Philippe FL, et al. On passion and sports fans: a look at football. J Sports Sci 2008; 26(12): 1279-93. [http://dx.doi.org/10.1080/02640410802123185] [PMID: 18803066] 
[2] Deloitte. Commercial breaks - Football money league In: Manchester: Sport Business Group 2015. Available at: http://www2.deloitte.com/na/en/pages/ audit/articles/deloitte-football-money-league.html

[3] Theodorakis N, Alexandris K, Tsigilis N, Karvounis S. Predicting spectators behavioural intentions in professional football: The role of satisfaction and service quality. Sport Manage Rev 2013; 16: 85-96. [http://dx.doi.org/10.1016/j.smr.2012.05.004]

[4] Biscaia R, Correia A, Yoshida M, Rosado A, Marôco J. The role of service quality and ticket pricing on satisfaction and behavioural intentions within professional football. Int J Sports Mark Spons 2013; 14: 301-25. [http://dx.doi.org/10.1108/IJSMS-14-04-2013-B004]

[5] Yoshida M, James J, Cronin JJ. Sport event innovativeness: Conceptualization, measurement, and its impact on consumer behavior. Sport Manage Rev 2013; 16: 68-84.

[http://dx.doi.org/10.1016/j.smr.2012.03.003]

[6] Martin D, O’Neill M, Hubbard S, Palmer A. The role of emotions in explaining consumer satisfaction and future behavioural intention. J Serv Mark 2008; 22: 224-36. [http://dx.doi.org/10.1108/08876040810871183]

[7] Yoshida M, James JD. Customer satisfaction with games and service experiences: Antecedents and consequences. J Sport Manag 2010; 24: 338-61.

[8] Biscaia R, Correia A, Ross S, Rosado A, Marôco J. Spectator-based brand equity in professional soccer. Sport Mark Q 2013 ; 22 : 20-32.

[9] Haugen KK, Solberg HA. The financial crisis in European football - A game theoretical approach. Eur Sport Manag Q 2010 ; 10 : 553-67. [http://dx.doi.org/10.1080/16184742.2010.524240]

[10] Mourao P. The indebtedness of Portuguese soccer teams-looking for determinants. J Sports Sci 2012; 30(10): $1025-35$. [http://dx.doi.org/10.1080/02640414.2012.685085] [PMID: 22574729]

[11] Woratschek H, Schafmeister G, Schymetzki F. International ranking of Sport Management Journals. In: Available from: http://www.dlm.uni-bay-reuth.de/de/pdfs/Infos/102_Wo_Scha_Schy_International_Ranking.pdf. Bayreuth: Universität Bayreuth, Rechts $\square$ und Wirtschaftswissenschaft-liche Fakultät 2009.

[12] Shilburry D. A bibliometric study of citations to sport management and marketing journals. J Sport Manag 2011; 25: 423-44.

[13] Shilburry D, Rentschler R. Assessing sport management journals: A multi-dimensional examination. Sport Manage Rev 2007; 10: 31 -44. [http://dx.doi.org/10.1016/S1441-3523(07)70002-5]

[14] McDonald MA, Sutton WA, Milne GR. TEAMQUAL: Measuring service quality in professional team sports. Sport Mark Q 1995; 4: 9-15.

[15] Teixeira PJ, Carraça EV, Marques MM, et al. Successful behavior change in obesity interventions in adults: a systematic review of selfregulation mediators. BMC Med 2015; 13: 84 .

[http://dx.doi.org/10.1186/s12916-015-0323-6] [PMID: 25907778]

[16] Ajzen I. Nature and operation of attitudes. Annu Rev Psychol 2001; 52: 27-58. [http://dx.doi.org/10.1146/annurev.psych.52.1.27] [PMID: 11148298]

[17] Bloom L. Intentionality and Theories of Intentionality in Development. essay review of developing theories of intention edited byp.d. zelazo, j.w. astington, and d.r. olson(1). Hum Dev 2000; 43(3): 178-85. [http://dx.doi.org/10.1159/000022674] [PMID: 10878469]

[18] Zeithaml VA, Berry LL, Parasuraman A. The behavioral consequences of service quality. J Mark 1996; 60(2): $31-46$. [http://dx.doi.org/10.2307/1251929]

[19] Bodet G, Bernache-Assollant I. Consumer loyalty in sport spectatorship services: The relationships with consumer satisfaction and team identification. Psychol Mark 2011; 28: 781-802. [http://dx.doi.org/10.1002/mar.20412]

[20] Biscaia R, Correia A, Ross S, Rosado A, Marôco J. Sport Spon: The relationship between team loyalty, sponsorship awareness, attitude toward the sponsor, and purchase intentions. J Sport Manag 2013; 27: 288-302.

[21] Bauer HH, Sauer NE, Exler S. The loyalty of German soccer fans: Does a team's brand image matter? Int J Sports Mark Spons 2005; 7: 14-22. [http://dx.doi.org/10.1108/IJSMS-07-01-2005-B004]

[22] Bauer HH, Stokburger NE, Exler S. Brand image and fan loyalty in professional sport team: A refined model and empirical assessment. J Sport Manag 2008; 22: 205-26.

[23] Theodorakis N, Alexandris K. Can service quality predict spectators' behavioral intentions in Professional soccer? Manag Leis 2008; 13: 162-78.

[http://dx.doi.org/10.1080/13606710802200852]

[24] Biscaia R, Correia A, Rosado A, Marôco J, Ross S. The effects of emotions on football spectators' satisfaction and behavioural intentions. Eur Sport Manag Q 2012; 12: 227-42. [http://dx.doi.org/10.1080/16184742.2012.679949]

[25] Yoshida M, Gordon B. Who is more influenced by customer equity drivers? A moderator analysis in a professional soccer context. Sport 
Manage Rev 2012; 15: 389-403.

[http://dx.doi.org/10.1016/j.smr.2012.03.001]

[26] Theodorakis N, Wann DL, Weaver S. An antecedent model of team identification in the context of professional soccer. Sport Mark Q 2013; 21: $80-90$.

[27] Yoshida M, Gordon B, Nakazawa M, Biscaia R. Conceptualization and measurement of fan engagement: Empirical evidence from a professional sport context. J Sport Manag 2014; 28: 399-417. [http://dx.doi.org/10.1123/jsm.2013-0199]

[28] Foroughi B, Shan KM, Nikbin D, Hyun SS. The impact of event quality on fan satisfaction and game attendance in the context of professional soccer in Iran. Int J Sports Mark Spons 2014; 15: 189-205. [http://dx.doi.org/10.1108/IJSMS-15-03-2014-B005]

[29] Edvardsson B. Service quality: beyond cognitive assessment. Manag Serv Qual 2005; 15: 127-31. [http://dx.doi.org/10.1108/09604520510585316]

[30] Ross S. A conceptual framework for understanding Spectator-Based Brand Equity. J Sport Manage 2006; 20 : 22-38.

[31] Zeithaml VA, Bitner MJ. Services marketing: Integrating customer focus across the firm. $3^{\text {rd }}$ ed. New York: McGraw Hill 2003.

[32] Ko YJ, Zhang J, Cattani K, Pastore D. Assessment of event quality in major spectator sports. Manag Serv Qual 2011; 21: $304-22$. [http://dx.doi.org/10.1108/09604521111127983]

[33] Theodorakis N, Alexandris K, Ko YJ. A service quality framework in the context of professional football in Greece. Int J Sports Mark Spons 2011; 12: 337-51. [http://dx.doi.org/10.1108/IJSMS-12-04-2011-B005]

[34] Biscaia R, Correia A, Menezes VG, Rosado A, Colaço C. Members's segmentation, service quality and behavioral intentions: A case study of a professional football team. Revista Intercontinental Gestão Desportiva 2012; (Suppl. 2)33-44.

[35] Jones MV, Lane AM, Bray SR, Uphill M, Catlin J. Development and validation of the sport emotion questionnaire. J Sport Exerc Psychol 2005; 27: 407-31.

[36] Bagozzi RP, Gopinath M, Nyer PU. The role of emotions in marketing. J Acad Mark Sci 1999; 27: $184-206$ [http://dx.doi.org/10.1177/0092070399272005]

[37] Moreno FC, Prado GV, Hervás JC, Núñez J, Sanz VA. Spectator emotions: Effect on quality, satisfaction, value, and future intentions. J Bus Res 2015; 68: 1445-9.

[http://dx.doi.org/10.1016/j.jbusres.2015.01.031]

[38] Couvelaere V, Richelieu A. Brand strategy in professional sports: The case of French soccer teams. Eur Sport Manag Q 2005; 5: 23-46. [http://dx.doi.org/10.1080/16184740500089524]

[39] Koenigstorfer J, Groeppel KA, Schmitt M. You'll never walk alone - How loyal are soccer fans to their clubs when they are struggling to relegation? J Sport Manag 2010; 24: 649-75.

[40] Lazarus RS. How emotions influence performance in competitive sports. Sport Psychol 2000; 14: $229-52$.

[41] Madrigal R. Investigating an evolving leisure experience: Antecedents and consequences of spectator affect during a live sporting event. J Leis Res 2003; 35: 23-48.

[42] Sumino M, Harada M. Affective experience of J. League fans: The relationship between affective experience, team loyalty, and intention to attend. Manag Leis 2004; 9: 181-92. [http://dx.doi.org/10.1080/1360671042000273855]

[43] Aaker DA. Building strong brands. New York: The Free Press 1996.

[44] Ross S, Russell K, Bang H. An empirical assessment of spectator-based brand equity. J Sport Manag 2008; 22 : 322-37.

[45] Keller KL. Conceptualizing, measuring, and managing customer-based brand equity. J Mark 1993; 57(1): 1-22. [http://dx.doi.org/10.2307/1252054]

[46] Keller KL. Brand synthesis: The multidimensionality of brand knowledge. J Consum Res 2003; 29: 595-600. [http://dx.doi.org/10.1086/346254]

[47] Bauer HH, Sauer NE, Schmitt P. Costumer-based brand equity in team sport industry: Operationalization and impact on the economic success of sport teams. Eur J Mark 2005; 39: 496-513. [http://dx.doi.org/10.1108/03090560510590683]

[48] Beccarini C, Ferrand A. Factors affecting soccer club season ticket holders' satisfaction: The influence of club image and fans' motives. Eur Sport Manag Q 2006; 6: 1-22. [http://dx.doi.org/10.1080/16184740600799154]

[49] Biscaia R, Ross S, Yoshida M, Correia A, Rosado A, Marôco J. Investigating the role of fan club membership on perceptions of team brand equity in football. Sport Manage Rev 2016; 19(2): 157-70. [http://dx.doi.org/10.1016/j.smr.2015.02.001]

[50] Cronin JJ, Taylor SA. Measuring service quality: A re-examination and extension. J Mark 1992; 56(3): 55-68. [http://dx.doi.org/10.2307/1252296] 
[51] Greenwell TC, Fink JS, Pastore DL. Assessing the influence of the physical sports facility on customer satisfaction within the context of the service experience. Sport Manage Rev 2002; 5: 129-48. [http://dx.doi.org/10.1016/S1441-3523(02)70064-8]

[52] Jones MA, Suh J. Transaction-specific satisfaction and overall satisfaction: An empirical analysis. J Serv Mark 2000; 14: 147-59. [http://dx.doi.org/10.1108/08876040010371555]

[53] Matsuoka H, Chelladurai P, Harada M. Direct and indirect effects of team identification and satisfaction on intention to attend games. Sport Mark Q 2003; 12: 244-52.

[54] Theysohn S, Hinz O, Nosworthy S, Kirchner M. Official supporters clubs: The untapped potential of fan loyalty. Int J Sports Mark Spons 2009; 10: 302-24.

[http://dx.doi.org/10.1108/IJSMS-10-04-2009-B004]

[55] Biscaia R, Correia C, Ross S, Rosado A. Sponsorship effectiveness in professional sport: An examination of recall and recognition among soccer fans. Int J Sports Mark Spons 2014; 16: 7-23. [http://dx.doi.org/10.1108/IJSMS-16-01-2014-B002]

[56] Ross S, James J, Vargas P. Development of a scale to measure team brand associations in professional sport. J Sport Manag 2006; 20: 260-79.

[57] Kim YK, Trail GT. Constraints and motivators: A new model to explain sport consumer behavior. J Sport Manag 2010; 24: 190-210.

[58] Cardoso J, Correia A, Biscaia R. A influência das restrições na lealdade dos espectadores de futebol: Sport Lisboa e Benfica. The influence of constraints on soccer spectators attendance: Sport Lisboa e Benfica. Revista Brasileira Ciências Esporte 2014; 36: 141-54. [http://dx.doi.org/10.1590/S0101-32892014000100010]

[59] Trail GT, Kim YK. Factors influencing spectators sports consumptions: NCAA Women's college basketeball. Int J Sports Mark Spons 2011; 13: 60-82.

[http://dx.doi.org/10.1108/IJSMS-13-01-2011-B006]

[60] Wicker P, Breuer C, Pawlowski T. Are sport club members big spenders? Findings from sport specific analyses in Germany. Sport Manage Rev 2010; 13: 214-24. [http://dx.doi.org/10.1016/j.smr.2009.07.001]

[61] Lock D, Taylor T, Funk D, Darcy S. Exploring the development of team identification. J Sport Manag 2012; 26: 283-94.

[62] McDonald H, Shaw RN. Satisfaction as a predictor of football club members' intentions. Int J Sports Mark Spons 2005; 2: 81-7.

[63] Liberati A, Altman DG, Tetzlaff J, et al. The PRISMA statement for reporting systematic reviews and meta-analyses of studies that evaluate health care interventions: explanation and elaboration. PLoS Med 2009; 6(7): e1000100. [http://dx.doi.org/10.1371/journal.pmed.1000100] [PMID: 19621070]

(c) Rui Biscaia; Licensee Bentham Open.

This is an open access article licensed under the terms of the Creative Commons Attribution-Non-Commercial 4.0 International Public License (CC BY-NC 4.0) (https://creativecommons.org/licenses/by-nc/4.0/legalcode), which permits unrestricted, non-commercial use, distribution and reproduction in any medium, provided the work is properly cited. 